\title{
Survival and Success of ITI Implants and Prostheses: Retrospective Study of Cases with 5-Year Follow-Up
}

\author{
Bilge Gokcen-Rohliga \\ Mehmet Yaltirik ${ }^{b}$ \\ Senem Ozerb \\ Ebru Demet Tuncera \\ Gulumser Evlioglua
}

\begin{abstract}
Objectives: The use of osseointegrated implants as an endoestal anchorage device to provide support for dental prostheses is a reliable and widely accepted treatment modality.

The purpose of this study was to evaluate the clinical performance of non-submerged implants placed in the maxilla or in the mandible.

Methods: A total of 146 International Team for Implantology (ITI) (Straumann AG, Waldenburg, Switzerland) implants were placed in 42 patients ( 20 women, 22 men, mean age 42). The cases were examined retrospectively in order to evaluate the clinical efficiency of non-submerged ITI implants and to determine the success rate of implant retained/supported prosthesis after a 5-year period. All implants were assessed clinically and radiographically on a yearly basis.

Results: The 5-year cumulative success rates for maxillary and mandibular implants were $91.00 \%$ and $97.81 \%$, respectively. The most common prosthetic complication was abutment accompanied by screw loosing (3.42\%). Veneering material fracture was documented in only one patient.

Conclusions: Within the limitations of the observation period and sample number, the present findings confirmed sufficient success and survival rates of ITI implants placed in mandible as well as implants placed in the maxilla after a 5-year period. (Eur J Dent 2009;3:42-49)
\end{abstract}

Key words: Cumulative success rate; Maxillary implants; Mandibular implants; Dental prosthesis.

a Department of Maxillofacial Prosthodontics, Faculty of Dentistry, Istanbul University, Turkey.

b Department of Oral Surgery, Faculty of Dentistry, Istanbul University, Turkey.

- Corresponding author: Dr. Bilge Gokcen-Rohlig Istanbul Universitesi Dis Hekimligi Fak.

Cene-Yüz Protezi Bilim Dalı

Capa 34093 Istanbul/Turkey

Phone: + 90212 4142020/30421 Fax: + 902126312249

E-mail: bgokcendistanbul.edu.tr

\section{INTRODUCTION}

The use of osseointegrated implants to support prosthetic reconstructions has become a common treatment modality for partial and complete edentulous patients. Dental implants made of commercially pure titanium initiated a revolution in dental practice. The early studies of Brånemark et $\mathrm{al}^{1,2}$ and Schroeder et $\mathrm{al}^{3,4}$ have been the pioneering clinical studies. They have discovered 
a direct bone-to-implant contact referred as osseointegration and obtained encouraging long term results in fully edentulous patients. 5,6 The original Brånemark concept was based on the rehabilitation of edentulous mandible with four or six implants inserted in intraforaminal zone and the implants were connected to each other with a fixed full-arch prosthesis with distal cantilevers, known as 'Toronto bridge'. In the last two decades, the original Brånemark concept has been greatly modified. There have been many advances in surgical and prosthetic protocols, as well as in implant materials, surfaces and forms. All these factors have broadened the applicability of implants and clinical guidelines have been established for predictable results. Now they are being used nearly in all fields of dentistry; in the treatment of partial and complete edentulism, in craniofacial surgery, and in orthodontics as anchorage device. ${ }^{2,6-11}$

The first clinical studies reporting the success of osseointegrated implants were retrospective studies of completely edentulous arches treated with Brånemark implants. ${ }^{5,6}$ The authors reported survival rates of $86 \%$ in mandible and $78 \%$ in the maxilla after 15 years of function. In course of time, many prospective studies were designed to examine the results of osseointegrated implants restored with fixed or removable prosthesis in edentulous arches. ${ }^{12-14}$ In a study, Ferrigno et $\mathrm{al}^{15}$ evaluated the long term prognosis of 1286 non-submerged ITI implants in fully edentulous arches and reported a cumulative survival rate of $95.9 \%$ and a cumulative success rate of $92.7 \%$ in ten years. Recently, Astrand et $\mathrm{al}^{16}$ reported 99.2\% survival rate in edentulous arches after 20 years of function. The successful outcome of the research that had been conducted in fully edentulous patients encouraged the clinicians to use the implants in the treatment of every kind of edentulism. In a prospective cohort study Bornstein et al $^{17}$ examined 104 osseointegrated implants in 51 partially edentulous patients and reported $99 \%$ survival and success rate at the end of 5 years of function. Similarly Romeo et al ${ }^{18}$ reported a cumulative survival rate of $99.35 \%$ and cumulative success rate of $96.18 \%$ for single tooth restoration in 5 years of function. The results of meta analysis studies and many other clinical studies show that osseointegrated implants as anchors for various prosthetic reconstructions are a predictable treatment alternative for long term. ${ }^{19-24}$

The purpose of this retrospective study was to evaluate the clinical performance of nonsubmerged implants placed in the maxilla or in the mandible over a period of 5 years.

\section{MATERIALS AND METHODS}

448 patients who were treated by the authors and received implant-supported/ retained prostheses were screened for the study. The inclusion criteria for enrollment in this study were (1) age between 18 and 65 years, (2) the presence of any kind of maxillary or mandibular edentulism (single tooth gap, distal extension, edentulous space in the ark, single tooth gap, fully edentulous), (3) sufficient bone volume at the surgical site (minimum bone height of 7 $\mathrm{mm}$ ) as assessed by clinical and radiological examination, (4) the absence of periodontal and mucosal diseases, and (5) good general health status. Of 102 recruited potential subjects, 60 were excluded for the presence of systemic diseases and radiation therapy because such conditions may complicate and/or contraindicate surgery and osseointegration. The final group of subjects enrolled in the study included 42 (20 women, 22 men) who had 146 implants installed in their maxillae and/or mandibles. The mean age of the enrolled patients at the time of implant placement was 48 years (range 20 to 66 years). The patients presented with one of five different indications (single tooth gap, distal extension, edentulous space in the ark and fully edentulous).

ITI implants IInternational Team for Implantology, Straumann AG, Waldenburg, Switzerland) were used in all cases. Implants with lengths of $8,10,12$ or $14 \mathrm{~mm}$ and diameters of $3.3,4.1$ or $4.8 \mathrm{~mm}$ were used. All implants were installed by the same surgeon from the Istanbul University Faculty of Dentistry Department of Oral Surgery. The prostheses were fabricated by the same prosthodontist at the Department of Maxillofacial Prosthodontics at Istanbul University.

Of the 146 implants examined here, 55 $(37.67 \%)$ were placed in the maxilla, including 22 that were placed in anterior positions (5 in females, 17 in males) and 33 that were placed in 
posterior positions (17 in females, 16 in males). Meanwhile, 91 (62.33\%) implants were placed in the mandible, including 29 that were placed in anterior positions (18 in females, 11 in males) and 62 that were placed in posterior positions (48 in females, 14 in males). The implant characteristics of implant recipient sides are summarized in Table 1. A total of 87 prosthetic restorations were connected to the implants (Table 2).

The surgical technique complied with the general guidelines defined by Brånemark et al ${ }^{25}$ and the specific indications recommended by Buser et $\mathrm{al}^{26}$ and by Buser and Maeglin ${ }^{27}$ for ITI implants. None of the implants included in this study were placed immediately after an extraction or loaded immediately after implant placement. Bone quality classification was performed at the time of surgery by the oral surgeon on the basis of hand-feeling persistence of the drilling resistance according to the classification of Trisi and Rao. ${ }^{28}$ Implants placed in sites with good bone quality (dense, normal) were examined after a healing period of two months in the maxilla or six weeks in the mandible. Implants placed in sites with poor bone quality (soft) were examined after a three-month healing period. The patients received clinical and radiographic evaluation at

Table 1. Classifications of implant recipient sites.

\begin{tabular}{|c|c|}
\hline Type of implant recipient site & $\begin{array}{l}\text { Number of } \\
\text { implants }\end{array}$ \\
\hline $\begin{array}{l}\text { Standard sites } \\
\text { (sufficient bone and keratinized } \\
\text { mucosa) }\end{array}$ & 48 \\
\hline $\begin{array}{l}\text { Maxillary sites with deficient posterior } \\
\text { alveolar ridge } \\
\text { (Sinus lifting or osteotome technique, } \\
\text { implant placement) }\end{array}$ & 31 \\
\hline $\begin{array}{l}\text { Sites with horizontal bone defect; } \\
\text { simultaneous GBR approach } \\
\text { (implant placement + membrane } \\
\text { application) }\end{array}$ & 36 \\
\hline $\begin{array}{l}\text { Sites with horizontal bone defect; } \\
\text { staged GBR approach } \\
\text { (bone grafting + membrane } \\
\text { application, no implant placement) }\end{array}$ & 41 \\
\hline Total & 146 \\
\hline
\end{tabular}

GBR: Guided Bones Regeneration. the above designated appropriate healing time. The implant immobility was tested digitally and the successfully osseointegrated implants were restored. Manufacturer-recommended screw torque values were used. The maxillary fullarch bridges were retained by implants placed in positions 11-13-15-16-21-23-25-26 and the mandibular in positions 33-34-35-36-43-44-4546. Patients who were treated with overdenture supported with dolder bars received the implants positioned in mandible 34-32-42-44, in maxilla 14-12-22-24. Overdentures supported with ball anchors received the implants installed in position 33-43. None of the overdentures in maxilla was supported with ball anchors.

At follow-up examinations, the implants were examined for tissue integration according to the strict parameters defined by Buser et al. ${ }^{29}$ Specifically, the integration was considered successful if the following parameters were met: (1) absence of recurring peri-implant infection with suppuration; (2) absence of persistent subjective complaints such as pain, foreign body sensation, and/or dysesthesia, (3) absence of a continuous radiolucency around the implant, and (4) absence of any detectable implant mobility. These criteria have proven to be effective in

Table 2. Prosthetic rehabilitation procedures performed.

\begin{tabular}{l|c|c|c}
\hline Prosthetic restoration & Maxilla & Mandible & Total \\
\hline $\begin{array}{l}\text { Full-arch bridge } \\
\text { (8 implants) }\end{array}$ & 8 & 8 & 16 \\
$\begin{array}{l}\text { Overdenture } \\
\text { (Dolder bar- } 4 \\
\text { implants) }\end{array}$ & ----- & 8 & 8 \\
$\begin{array}{l}\text { Overdenture } \\
\text { (Ball anchors } 2 \\
\text { implants) }\end{array}$ & ----- & 6 & 6 \\
\hline $\begin{array}{l}\text { Single tooth } \\
\text { replacement }\end{array}$ & 21 & 27 & 48 \\
\hline $\begin{array}{l}\text { Short-span fixed } \\
\text { bridges }\end{array}$ & 26 & 42 & 68 \\
\hline \begin{tabular}{l} 
Total \\
\hline
\end{tabular} & 55 & 91 & 146 \\
\hline
\end{tabular}


defining the success of an implant system and evaluating long-term results in clinical trials. All implants were subsequently assessed clinically and radiographically at seven followup examinations which occurred 1, 6, 12, 18, 24, 48 and 60 months after prosthesis placement. Radiographic evaluation was performed by either periapical radiographs obtained by long-cone paralleling technique or panoramic radiographs. In patients who were treated with overdentures or full-arch bridges supported with multiple implants a panoramic radiograph was used. In partially edentulous patients periapical radiographs were used. Radiographs were analyzed for presence peri-implant radiolucencies. Mesial and distal bone levels of each implant were measured with a transparent millimeter ruler and the measurements were compared with those recorded at the baseline measurement. Because of the relatively small sample size of the study population, statistical analysis of the data regarding marginal bone level loss was not performed. A qualitative evaluation based on the implant success criteria defined by Buser et al ${ }^{29}$ was carried out.

The patients were also evaluated for symptoms of pain, prosthesis mobility and evidence of infection and any adverse reaction reported by the patients was also recorded.

\section{Statistical analysis}

The statistical analysis was performed at the beginning of 2007 according to the life table analysis described by Cutler and Ederer. ${ }^{30}$ Life tables included the following parameters: observation time, number of implants at the start of each interval, number of failed implants during each interval, number of implants not subjected to follow-up examination due to patient drop-out, annual survival and success rates and cumulative survival and success rates. Cumulative success rates, which took into account failure conditions in addition to failed implants, were calculated for each jaw. The formula used for the calculations in this study is as follows:

$$
\text { CSR }=\text { PCSR+ }+((I S R \times 100-P C S R)) / 100
$$

ICSR: Cumulative success rate, PCSR: Previous cumulative success rate, ISR: interval success rate)

\section{RESULTS}

Of 448 implant patients treated by the authors, 102 patients were included in the study. Of these 102 recruited potential subjects, 60 were excluded for the presence of systemic diseases and radiation therapy. Finally 42 (20 women, 22 men) subjects who had 146 implants installed in their maxillae and/or mandibles were enrolled in the study. The mean age of the patients at the time of implant placement was 48 years (range 20 to 66 years). The patients presented with one of five different indications (48 single tooth gap, 38 distal extensions, 30 edentulous spaces in the ark, 30 fully edentulous). $74.02 \%$ of single and multiple-unit implant retained bridges were cemented and $26.08 \%$ were screw retained.

Three patients did not complete their followups for personal reasons. The mean time period between implant insertion and abutment connection was 2.1 months. Of the 146 examined implants, 4 ltwo in anterior maxilla, one in posterior maxilla, one in posterior mandiblel did not integrate before loading and revealed periimplant infection with suppuration. We considered these as early failure and this resulted in $2.74 \%$ early failure rate (Tables 3 and 4). These implants were replaced with new implants 3 months after the implant removal and demonstrated complication free hard and soft tissue integration. These were not included in the study. During the healing period the remaining implants showed no clinical signs of inflammation and/or periimplant radiolucencies.

Four implants were surgically removed during the 5-year follow-up period, primarily due to recurrent peri-implant infection (Table 3). All of the failed implants demonstrated continuous peri-implant radiolucencies. They were $3.3 \mathrm{~mm}$ in diameter and $10 \mathrm{~mm}$ in length. The remaining implants osseointegrated in bone and did not show signs of peri-implant infection and/or peri-implant radiolucencies. The most common (3.42\%) prosthetic complication was abutment and screw loosening (Table 5). Veneering material fracture was observed in only one patient.

The interval examination and entire 5-year period success rates are summarized in Table 6. The cumulative one-year survival rates of implants were $97.37 \%$ for the maxilla and $97.80 \%$ for the mandible. The five-year success rates 
were $90.90 \%$ for both the anterior and posterior maxilla. The five-year success rates were $100 \%$ for the anterior mandible and $96.72 \%$ for the posterior mandible. Hence, the life analysis indicated that the 5 -year functioning cumulative success rates were $90.90 \%$ for maxillary implants and $97.80 \%$ for mandibular implants.

\section{DISCUSSION}

This study retrospectively examined a cohort of 42 patients who presented with a variety of indications in both jaws over a 5 -year period and confirmed good performance of the ITI Dental Implant System in the treatment of edentulism that was consistent with previously reported short-term and long-term success and survival rates of the system. ${ }^{15,18,31,32}$ The quality of an implant system must be judged scientifically. Since 1978, several criteria schemes proposed for assessing implant success have been proposed,

Table 3. Distribution and timing of implant failures.

\begin{tabular}{|c|c|c|c|c|c|}
\hline \multirow{2}{*}{ Implant location } & \multirow{2}{*}{$\begin{array}{c}\text { No of implants } \\
\text { inserted }\end{array}$} & \multirow{2}{*}{$\begin{array}{l}\text { Early failures } \\
\text { during healing }\end{array}$} & \multicolumn{3}{|c|}{ Implant removal } \\
\hline & & & $\leq 1$ year & $1-2$ years & $2-4$ years \\
\hline Maxilla Anterior & 22 & 2 & 1 & - & - \\
\hline Maxilla Posterior & 33 & 1 & 2 & - & - \\
\hline Mandible Anterior & 30 & - & - & - & - \\
\hline Mandible Posterior & 61 & 1 & - & - & 1 \\
\hline Total & 146 & 4 & 3 & - & 1 \\
\hline
\end{tabular}

Table 4. Characteristics of failed implants.

\begin{tabular}{l|c|c|c|c}
\hline Implant location & Failure time & Implant length & Implant diameter & Reason for failure \\
\hline 24 & Early & $10 \mathrm{~mm}$ & $3.3 \mathrm{~mm}$ & Mobility \\
35 & Early & $10 \mathrm{~mm}$ & $3.3 \mathrm{~mm}$ & Mobiliy \\
26 & Early & $10 \mathrm{~mm}$ & $3.3 \mathrm{~mm}$ & Mobility \\
14 & Early & $10 \mathrm{~mm}$ & $3.3 \mathrm{~mm}$ & Progressive bone loss \\
21 & Late & $10 \mathrm{~mm}$ & $3.3 \mathrm{~mm}$ & Ongoing infection \\
45 & Late & $10 \mathrm{~mm}$ & $3.3 \mathrm{~mm}$ & Mobility \\
14 & Late & $10 \mathrm{~mm}$ & $3.3 \mathrm{~mm}$ & Mobility \\
\hline
\end{tabular}

Table 5. Prosthetic complications encountered in the study.

\begin{tabular}{lcccc} 
& Screw loosening & Abutment loosening & Veneer fracture & Abutment fracture \\
\hline Mandible & 1 & 1 & 4 & 1 \\
Maxilla & 4 & 2 & 3 & 1 \\
\hline
\end{tabular}

Table 6. Success rates and cumulative success rate of implants.

\begin{tabular}{|c|c|c|c|c|c|}
\hline Interval (years) & $\begin{array}{c}\text { Implants at start } \\
\text { of interval }\end{array}$ & $\begin{array}{l}\text { Drop outs during } \\
\text { interval }\end{array}$ & $\begin{array}{c}\text { Failures during } \\
\text { interval }\end{array}$ & $\begin{array}{c}\text { Success rate } \\
\text { within period } \\
(\%)\end{array}$ & $\begin{array}{c}\text { Cumulative } \\
\text { success rate } \\
(\%)\end{array}$ \\
\hline $0-1$ & 146 & 2 & 2 & 93.55 & 93.55 \\
\hline $1-2$ & 115 & 0 & - & 100 & 93.55 \\
\hline $2-3$ & 93 & 1 & 2 & 95.45 & 89.29 \\
\hline $3-4$ & 49 & 0 & 3 & 93.87 & 83.81 \\
\hline $4-5$ & 49 & 0 & 3 & 93.87 & 83.81 \\
\hline
\end{tabular}


beginning with the first success criteria scheme described by the National Institutes of Health in $1978^{33}$ followed by Albrektsson et al's $\mathrm{s}^{34}$ and Buser et al's ${ }^{29}$ progressively stricter schemes in 1986 and 1990. As elaborated in the methods, here we used Buser et al's ${ }^{29}$ strict parameters for evaluating implant system success and longterm clinical trial results.

Life table analysis performed according to the recommendations of Cutler and Ederer ${ }^{30}$ proved to be an appropriate and rather conservative statistical method for examining the long-term success and survival rates of osseointegrated implants. ${ }^{15,31}$ This study revealed a distinction between implant survival and success according to the defined criteria.

Consistent with prior reports, we observed greater success rates for mandibular implants than for maxillary implants. ${ }^{18,26,31}$ While our 5 -year functioning cumulative success rate for mandibular implants $(97.80 \%)$ was consistent with the literature, our 5-year functioning cumulative success rate for maxillary implants (90.90\%) was lower than that reported previously. In a large multi-center prospective study, Buser ${ }^{31}$ reported a 5 -year success rate of $97.30 \%(13$ failures/488 implants) and 5 -year survival rate of $98.20 \%$ (9 losses/488 implants) in the maxilla. Weber et al ${ }^{35}$ reported an impressive cumulative 5 -year survival rate of $99.1 \%$. The slightly lower rate observed for maxillary implants here is most likely related to the status of the recipient sites, as only $32.8 \%$ of the implants were placed in standard sides. Advanced surgical techniques, such as guided bone regeneration and sinus floor augmentation, may be used to increase the bone volume and enable the placement of dental implants in atrophic ridges, but they present greater risks compared to standard sides and demonstrate lower success rates. ${ }^{36,37}$ Weber $^{35}$ did not consider the status of implant recipient side.

Among the 146 implants studied here, there were three that failed and four that were surgically removed. The three failed implants reported here were not associated with any clinical signs of periimplant infection with suppuration. Our low early failure rate was consisted with those previously reported. ${ }^{18,32}$ Early failure of the implants in these cases may have been caused by bone necrosis due to overheating of the peri-implant bone during the preparation of implant bed. It is worth noting that in all three of these cases, the implants were located in the posterior maxilla at sites with poor bone quality and sinus floor elevation. The primary reason for surgical removal of the four removed implants was recurrent peri-implant infection.

The most important factor in the reliability of the results of clinical studies reporting success and survival rate is that they should have a predefined, strict protocol with at least five years of clinical documentation from which dropsouts, failures, success and survival rates in the initial sample groups can be extrapolated. $30,34,39$ Although the present study did not employ a prospective design, the reliability of the data is enhanced given then only implants that were placed following a strict protocol Iroutine clinical and radiographic controls) and followed for a full 5 years were included. While our requirement for use of a strict protocol was important for improving data reliability, it did ultimately reduce the sample number relative to prior research reporting success and survival rates for periods of at least 5 years. ${ }^{31}$

\section{CONCLUSIONS}

Within the limitations of the observation period and sample number, the present findings confirmed sufficient success and survival rates of ITI implants placed in mandible as well as implants placed in the maxilla.

\section{ACKNOWLEDGEMENTS}

A portion of these data were presented in a poster at the ITI World Symposium in New York City (April 26-28, 2007).

\section{REFERENCES}

1. Brånemark PI, Breine U, Adell R, Hannsson BO, Lindström J, Öhman A. Intra-osseous anchorage of dental prostheses. Experimental studies. Scand JPlast Reconstr Surg 1969;11:81100

2. Brånemark $\mathrm{PI}$, Hannsson $\mathrm{B}$, Adell $\mathrm{R}$, Breine $\mathrm{U}$, Lindström $J$, Öhman A. Osseointegrated implants in the treatment of the edentulous jaw. Experience from a 10 year period. Scand J Plast Reconstr Surg 1977;11:1-132

3. SchroederA, Pohler O,SutterF.Gewebereaktionaufein TitanHohlzylinderimplantat mit Titan Spritzschichtoberflache. Schweiz Monatsschr Zahnheilkd 1976;86:713-727. 
4. Schroeder A, van der Zypen E, Stich H, Sutter F. The reactions of bone, connective tissue, and epithelium to endosteal implants with titanium-sprayed surfaces. $J$ Maxillofac Surg 1981;9:15-35.

5. Adell R, Lekholm U, Rocler B, Brånemark PI. A 15-year study of osseointegrated implants in the treatment of edentulous jaw. Int J Oral Surg 1981;10:387-416.

6. Adell, R, Eriksson B, Lekholm U, Brånemark PI, Jemt T. Long-term follow- up study of osseointegrated implants in the treatment of totally edentulous jaws. Int $J$ Oral Maxillofac Implants 1990;5:347-359.

7. Belser UC, Schmid B, Higginbottom F, Buser D. Outcome analysis of implant restorations located in the anterior maxilla: a review of the recent literature. Int $J$ Oral Maxillofac Implants 2004;19:30-42.

8. Naert I, Koutsikakis G, Duyck J, Quirynen M, Jacobs R, van Steenberge D. Biologic outcome of implant-supported restorations in the treatment of partial edentulism. Part I: a longitudinal clinical evaluation. Clin Oral Implants Res 2002;13:381-389.

9. Attart NJ, Zarb GA. Long-term treatment outcomes in edentulous patients with implant overdentures: the Toronto study. Int J Prosthodont 2004;17:425-433.

10. Toljanic JA, Eckert SE, Roumanas E, Beumer J, Huryn JM, Zlotolow, IM, Reisberg DJ, Habakuk SW, Wright RF, Rubenstein JE, Schneid TR, Mullasseril P, Garcia LT, Bedard JF, Choi YG. Osseointegrated craniofacial implants in the rehabilitation of orbital defects: an update of a retrospective experience in the United States. J Prosthet Dent 2005;94:177-182.

11. Shapiro PA, Kokich VG. Uses of implants in orthodontics. Dent Clin North Am 1988;32:539-555.

12. Zarb GA, Schmitt A. The longitudinal clinical effectiveness of osseointegrated implants. Toronto study. Part 1: Surgical results. J Prosthet Dent 1990;63:451-457.

13. Zarb GA, Schmitt A. The longitudinal clinical effectiveness of osseointegrated dental implants in anterior partially edentulous patients. Int J Prosthodont 1993;6:180-188.

14. Zarb GA, Schmitt $A$. The longitudinal clinical effectiveness of osseointegrated dental implants in posterior partially edentulous patients. Int J Prosthodont 1993;6:189-196.

15. Ferrigoni N, Laureti M, Fanali S, Grippaudo G. A longterm follow-up of non-submerged ITI implants in the treatment of totally edentulous jaws. Clin Oral Implants Res 2002;13:260-273.

6. Astrand P, Ahlqvist J, Gunne J, Nilson H. Implant treatment of patients with edentulous jaws: A 20-Year follow-up. Clin Implant Dent Relat Res 2008;10:207-217.
17. Bornstein MM, Schmid B, Belser UC, Lussi A, Buser D. Early loading of non-submerged titanium implants with a sandblasted and acid-etched surface. 5-year results of a prospective study in partially edentulous patients. Clin Oral Implants Res 2005;16:631-638.

18. Romeo E, Chiapasco M, Ghisolfi M, Vogel G. Long-term clinical effectiveness of oral implants in the treatment of partial edentulism. Clin Oral Implants Res 2002;13:133-143.

19. Wedgwood D, Jennings KJ, Critchlow HA, Watkinson AC, Shepherd JP, Frame JW. Laird WRE, Quatle AA. Experience with ITI osseointegrated implants at five centers in UK. Br J Oral Maxillofac Surg 1992;30:377-381.

20. Behneke A, Behneke N, d'Hoedt B, Wagner W. Hard and soft tissue reactions to ITI screw implants: a 3 year longitudinal results of a prospective study. Int J Oral Maxillofac Implants 1997;12:749-757.

21. Brägger U, Huge-Pisoni C, Bürgin W, Buser D, Lang NP. Correlations between radiographic, clinical and mobility parameters after loading of oral implants with fixed partial dentures. A 2-year longitudinal study. Clin Oral Implants Res $1996 ; 7: 230-239$

22. Ellegaard B, Baelum V, Karring T. Implant therapy in periodontally compromised patients. Clin Oral Implants Res 1997;8:180-188.

23. Lindh T, Gunne J, Tillberg A, Molin M. A meta-analysis of implants in partial edentulism. Clin Oral Implants Res 1998;9:80-90.

24. van Steenberghe D, Bolender C, Henry P, Higuchi K, Linden $U$. The applicability of osseointegrated oral implants in the rehabilitation of partial edentulism: a prospective multicenter study on 558 fixtures. Int $J$ Oral Maxillofac Implants 1990;5:272-281.

25. Brånemark PI. Introduction to osseointegration In: Brånemark PI, Zarb GA. \& Albrektsson T leds) Tissueintegrated prostheses: Osseointegration in Clinical Dentistry. Chicago, Illinois: Quintessence Publishing Co. 1985.

26. Buser, D, Weber HP, Lang NP. Tissue integration of nonsubmerged implants. One-year results of a prospective study with $100 \mathrm{ITI}$ hollow-screw and hollow-cylinder implants. Clin Oral Implants Res 1990;1:33-40.

27. Buser D, Maeglin B. Surgical procedures with ITI implants. In: Schroeder A, Sutter F, Buser D \& Krekeler G, (eds). Oral Implantology New York: Thieme Publishers Inc. 1996;256329.

28. Trisi P, Rao W. Bone classification: clinicalhistomorphomometric comparison. Clin Oral Implants Res 1999;10:1-7. 
29. Buser D, Weber HP, Braegger U. The treatment of partially edentulous patients with ITI hollow-screw implants; presurgical evaluation and surgical procedures. Int J Oral Maxillofac Implants 1990;5:165-174.

30. Cutler SJ, Ederer F. Maximum utilization of the life table method in analyzing survival. J Chronic Disease 1958;6;699712.

31. Buser D, Mericske-Stern R, Behneke A, Behneke N, Hirt HP, Belser UC, Lang NP. Long term evaluation of nonsubmerged ITI implants. Part 1: 8-year life-table analysis of a prospective multi-center study with 2359 implants. Clin Oral Implants Res 1997;8:161-172.

32. Arlin ML. Survival and success of sandblasted, large-grit, acid-etched and titanium plasma-sprayed implants: a retrospective study. J Can Dent Assoc 2007;73:821.

33. Schnitmann, PA, Schulman LB. Recommendation of the consensus development conference on dental implants. $J$ Am Dent Assoc 1979;98:373-377.

34. Albrektsson T, Zarb D, Worthington P, Eriksson AR. The long term efficacy of currently used dental implants: a review and proposed criteria of success. Int $J$ Oral Maxillofac Implants 1986;1:11-25.

35. Weber HP, Crohin CC, Fiorellini JP. A 5-year prospective clinical and radiographic study of non-submerged dental implants. Clin Oral Implants Res 2000;11:144-153.

36. Simion M, Misitano U, Gionso L, Salvato A. Treatment of dehiscences and fenestrations around dental implants using resorbable and non-resorbable membranes associated with bone autografts: a comparative clinical study. Int J Oral Maxillofac Implants 1997;12:159-167.

37. Jensen OT, Schulman LB, Block MS, lacono VJ. Report of the Sinus Consensus Conference of 1996. Int J Oral Maxillofac Implants 1998;13:11-45. 